\title{
Effect of two different types of concentrate on dry matter intake, body weight gain and body growth of Pyar Sein calves fed Black Gram crop residue
}

\author{
K.S. Win ${ }^{1 *}$, Y. Aung ${ }^{2}$, Z.T. Kyaw ${ }^{1}$, K.K. Lay ${ }^{2}$, H.L. Oo ${ }^{2}$ \\ ${ }^{1}$ Livestock Demonstration Farms, ${ }^{2}$ Department of Animal Science, University of Veterinary Science, Yezin, Nay Pyi \\ Taw, 15013, Myanmar \\ *Corresponding author: Email_ kyawsanwinksw08@gmail.com; Phone: +959797684066, Fax: +95 673416528 \\ Journal of Livestock Science (ISSN online 2277-6214) 12: 65-70 \\ Received on 1/10/20; Accepted on 20/12/2020; Published on 7/1/2021 \\ doi. 10.33259/JLivestSci.2021.65-70
}

\begin{abstract}
The objective of this experiment was intended to evaluate the potential effect of given black gram (Vigna munga) crop residue (BGR) with different types of concentrates on dry matter intake and growth performance of local calves. Ten male local (Pyar Sein) calves were allotted to two concentrate groups: one is commercial concentrate (CC) pellet and the other is homemade concentrate (HC). Both concentrates were provided on a dry matter basis of $1 \%$ body weight (BW) of calves per day to the associative group. The homemade concentrate group had significantly lower daily intakes of BGR $(1.84 \mathrm{vs} .1 .98 \mathrm{~kg})$ and total dry matter $(4.41 \mathrm{vs} .5 .35 \mathrm{~kg})$ than the group fed commercial concentrate; however, dry matter intakes of calves expressed as percent of BW did not differ. No significant differences were observed between the groups for mean body weight gain, mean daily gain (MDG) and mean feed conversion efficiency. Developments in body parts (such as body length, chest girth, wither height and rump height) were not significantly different between the two concentrate groups. The black gram crop residue could be used as basal roughage in local Pyar Sein calves fed homemade concentrate without showing negative efficiency in daily weight gain, feed conversion efficiency and growth of body parts.
\end{abstract}

Key words: black gram (Vigna munga) crop residue; homemade concentrate; commercial concentrate pellet; dry matter intake; body growth; Pyar Sein calves 
Win et al 2021/J Livestock Sci. 12: 65-70

\section{Introduction}

The export of live draught cattle by Myanmar have increased sharply due to the growing a high demand for beef from China and Vietnam markets. In the fiscal year 2019-2020, the income of exporting beef cattle was registered at US\$222.5 million (GNLM, 2020). However, the called developing countries in Southeast Asia such as Cambodia, Laos PDR and Myanmar show poor beef production efficiency in smallholder farms. Because tropical livestock in this region are normally based on natural pasture and crop residues, which have protein and energy deficiencies that influence cattle production (Sommart, 1998). In Myanmar, the total population of draught cattle was 9.6 million heads. The well-known cattle breeds for beef are Pyar Sein breed which are tall and white in colour, and are dominantly populated in dry zone and upper regions; and Shwe Ni breeds are red colour and highly reared in the lower part of Myanmar including Mandalay and Magway divisions (Luong Pham et al., 2015). Most of the draught cattle are kept under traditional systems, usually in a small household herd of greater than four heads of draught cattle. The three divisions of Mandalay, Sagaing and Magway, regarded as the central dry zone (CDZ), had over half (52\%) of the national cattle population (NLBS, 2019). The draught cattle in the CDZ seriously face the seasonal scarcity of roughage sources because of the long dry season in every year. To alleviate this feed shortage in the summer season, farmers collect crop residues and store them for later use in stall feeding. One of the constraints in tropical beef production, low quality feedstuff, such as rice straw, sorghum straw, black gram residue and green gram residue is the major roughage source of draught cattle owned by small household farmers in the CDZ. Previous many studies have indicated that supplementation of energy and/or protein-rich feed to crop residuebased diet is necessary for satisfactory performance of ruminants.

Research on feeding management to improve draught or beef cattle production and to sustain small-scale farms in Myanmar using regionally available feedstuff resources is urgently required. As a consequence work, knowledge of feed requirement and feed formulations in trying the development of a feeding system are necessary (Khemsawat and Phonbumrung, 2008). The largest production of black gram (Vigna munga) or Urad (Matpe) is India, followed by Myanmar and Thailand. In Myanmar, the most production area of black gram beans is the dry region (Mandalay, Sagaing), which has an annual average rainfall of about $800 \mathrm{~mm}$. It can also be grown in hilly regions such as Kachin, Shan, Mon States, and delta regions like Ayeyarwaddy, Bago Divisions (Myanmar Pulses, Beans \& Sesame Seeds Merchants Association, 2019). A considerable quantity of straw, pods and foliage are generated as byproducts during the collection of black gram seeds, which could be applied to ruminant production (Arulnathan et al., 2013.). Studies with black gram crop residue as a supplement together with rice straw (Tin Maung Soe et al. 2007) and as a roughage source in complete ration or complete block (Venkateswarlu et al., 2013) have been reported in ruminants. Although these legume residues such as groundnut, black gram and green gram are commonly used for the draft cattle and small scale crossbred dairy cows together with rice straw in Myanmar, little information is available about their potential for the ruminant feed as a basal diet. Thus, the current study was intended to find potential basal roughage of black gram crop residue feeding local calves with homemade concentrate from industrial byproducts competing with commercial concentrate in summer months.

\section{Materials and Methods}

This feeding experiment was started on $23^{\text {rd }}$ February, 2020 with local calves (Pyar Sein) and conducted at the Livestock Demonstration Farms, University of Veterinary Science, Yezin, Nay Pyi Taw. The experimental procedures consisting of animal care, management and sample collection were performed according to the Guidelines of Committee of Animal Experiments of the University of Veterinary Science, Myanmar.

Ten male local (Pyar Sein) calves of approximately 10-12 months of age with a live body weight (BW) of $154.3 \pm 16.7 \mathrm{~kg}$ were used in this feeding trial. These ten male calves were randomly and equally allotted into the following two dietary treatment groups: homemade concentrate supplement $(\mathrm{HC})$ and commercial concentrate supplement (CC). Before the beginning of the experiment, calves were treated for external and internal parasites with Vimectin as prescribed by the manufacturer (Vemedim Animal Health, Can Tho City, Vietnam). Before data collection, calves were adapted to the feeding management for 9 days, when they were fed black gram crop residue ad libitum, and commercial concentrate and homemade concentrate at $1.0 \%$ of $\mathrm{BW}$. The homemade concentrate and commercial concentrate pellets used in the current feeding trial were the same as Win et al., 2020.

The black gram crop residue (BGR) applied in this experiment was obtained from the Nay Pyi Taw area. The black gram residue included edible parts (stems, leaf pieces and pod husks) of the plant remaining after seed production and originated from the farmer's fields. The basal diet BGR was collected between mid-February and March for feeding during the summer season (March-May). Calves in both groups were fed on BGR ad libitum, and the refusal rate was of about $10 \%$ throughout the experimental period. Homemade concentrate and commercial 
concentrate were fed to the groups $\mathrm{HC}$ and $\mathrm{CC}$ at a rate of $1.0 \%$ (on a dry matter basis) of BW per day. The amounts of $\mathrm{HC}$ and $\mathrm{CC}$ were determined for individual calves on the basis of their BW, and adjusted biweekly to account for BW changes. The chemical composition of black gram crop residue, homemade concentrate and commercial concentrate pellet used in this feeding trial are shown in Table 1.

The black gram crop residue, homemade concentrate and commercial concentrate pellet were offered in two times; morning meal and evening meal throughout the feeding period which lasted for 99 days including 9 days adaptation period. Amounts of feed offered and refused were recorded daily to estimate feed intake. Subsamples of offered feed and residues were taken weekly for dry matter (DM) determination. To monitor BW change, claves were weighed every 15 days before feeding in the morning. The average daily gain was calculated by dividing the initial and final BW differences by total days of feeding trial (90 days).

The feeds and refusals were oven dried at $70^{\circ} \mathrm{C}$ for 48 hours for dry matter (DM) determination. Dried feeds were milled to pass through a $1 \mathrm{~mm}$ sieve using a Wiley mill, and stored in plastic bottles for analysis. Nitrogen (N) and ash were determined according to AOAC (1990). The content of organic matter (OM) was calculated by subtracting ash from 100 . The crude protein $(\mathrm{CP})$ content was calculated as $\mathrm{N} \times 6.25$. Neutral detergent fibre (NDF) and acid detergent fibre (ADF) were determined as described by Van Soest et al. (1991).

The body weights of local cattle were recorded by using Cattle Weight Bridge in this feeding research. It is the most accurate method of weighing feedlot cattle. Calves were also weighed directly using the monitor digital electrical scale equipment tool with the maximum capacity of $2000-3000 \mathrm{~kg}$. The actual weight value in kilogram was directly read on the monitor of electrical weighing indicator when the calves were weighing. After weighing, body measurements of calves were continuously recorded. When calves were measured for body parts, they had to be standing with the correct posture; their dorsal line and cheek had to make a straight line, and their four hooves had to make a rectangle. Body parts were measured by measuring stick except chest girth or heart girth which was measured with measuring tape according to the reference Textbook of Field Practices in Bio-resource Production, University of Tsukuba, Japan.

The average dry matter intake (DMI), weight gain, daily weight gain, feed conversion efficiency and body measurements such as chest girth, body length, wither height and rump height for each calf were obtained repeatedly over the feeding period. Data on these parameters were subjected to Student's t test (Snedecor \& Cochran, 1994), using repeated measures, at $5 \%$ probability. Data on BW of each calf were also analysed using Student's t test at $5 \%$ probability.

\section{Results and Discussion}

The application efficiency and management of by-products released from agriculture and industries are crucial factors in sustainable development goals for livestock farming. The black gram crop residue is one of the three major crop residual resources in India and Myanmar. On the other hand, lablab bean husk (LLBH) is an industrial waste and is a by-product of soaking lablab bean processed for the production of fried bean seed. The nutrient intake and digestibility of the poor quality feeds can be increased by the use of various techniques for processing and supplementing (Leng, 1990). The utilization of black gram foilage (Dey et al., 2017) and LLBH waste (Win et al., 2020) in ruminant feeding has been evaluated.

Dry matter intake of buffalo did not differ among four iso-nirogenous complete rations formulating of jowar straw, maize stover, red gram straw and black gram straw (Venkateswarlu et al., 2013). In our experiment, male calves given $1 \% \mathrm{HC}$ or $\mathrm{CC}$ of $\mathrm{BW}$ in DM basis ate all the offered supplemental feed (Table 2). Calves on the HC group significantly possessed lower dry matter intake of BGR (2.93 vs $3.67 \mathrm{~kg}$ per day) and total dry matter intake (4.41 vs $5.35 \mathrm{~kg}$ per day) than those fed CC. The observed result in this feeding experiment could probably be due to the small initial body weight of the local calves. Another possible reason is lablab bean husk included in homemade concentrate which can absorb or hold water capacity causes greater rumen fill. Intake is regulated by physical factor such as ruminal fill (Jarrige, 1989) and ruminal passage rate of small particles (Win et al., 2015). The DMI of the local Pyar Sein calves in this experiment agreed with the recommended dry matter intake of Thai native cattle (WTSR, 2010). Dry matter intake of BGR as expressed \%BW for both grouped calves did not significantly differ (HC: $1.84 \%$ vs CC: $1.98 \%)$, this was lower than an average dry matter intake of cattle $(2.2 \%$ of BW) observed by Grant et al. (1974) and Muinga et al. (1992). However, total dry matter intakes described as $\mathrm{kg} /$ day and \% BW of local cattle were in agreement with the study results of Vietnam local cattle by Dung et al. (2013).

The results of weight gain and feed conversion efficiency (FCE) of local calves given homemade concentrate (HC) and commercial concentrate (CC) are shown in Table 2. In this feeding trial for fattening process, $\mathrm{CC}$ grouped calves attained greater mean weight gain $(66.00 \mathrm{~kg})$ and mean daily gain $(732.40 \mathrm{~g} / \mathrm{day}) \mathrm{compared}$ to $\mathrm{HC}$ 
Table 1 Chemical composition of experimental feedstuffs (\%)

\begin{tabular}{|l|l|l|l|l|l|}
\hline Feedstuffs & DM & OM & CP & NDF & ADF \\
\hline Black gram crop residue(BGR) & 92.1 & 93.7 & 10.1 & 62.5 & 46.6 \\
\hline Cottonseed meal & 90.0 & 93.9 & 27.2 & 38.0 & 25.5 \\
\hline Lablab bean husk & 92.6 & 94.2 & 8.8 & 60.5 & 46.5 \\
\hline Homemade concentrate (HC) & 89.8 & 85.3 & 19.2 & - & - \\
\hline Commercial concentrate (CC) & 88.2 & 78.8 & 20.0 & - & - \\
\hline
\end{tabular}

DM: dry matter; OM: organic matter; CP: crude protein; NDF: neutral detergent fiber; ADF: acid detergent fiber

Table 2. Dry matter intake and growth performances of local male calves by two types of concentrates

\begin{tabular}{|l|l|l|l|}
\hline Items & HC & CC & P-value \\
\hline Initial body weight $(\mathrm{kg})$ & 142.70 & 165.90 & \\
\hline Final body weight $(\mathrm{kg})$ & 197.80 & 231.90 & \\
\hline Weight gain $(\mathrm{kg})$ & 55.10 & 66.00 & $\mathrm{NS}$ \\
\hline Mean daily gain $(\mathrm{MDG})(\mathrm{g} /$ day) & 612.70 & 732.40 & $\mathrm{NS}$ \\
\hline Dry matter intake of BGR $(\mathrm{kg})$ & 2.93 & 3.67 & $<0.01$ \\
\hline Total dry matter intake $(\mathrm{kg})$ & 4.41 & 5.35 & $<0.01$ \\
\hline Dry matter intake of BGR $(\%$ of BW) & 1.84 & 1.98 & $\mathrm{NS}$ \\
\hline Total dry matter intake $(\%$ of BW) & 2.77 & 2.89 & $\mathrm{NS}$ \\
\hline Feed conversion efficiency (FCE) & 7.8 & 7.83 & $\mathrm{NS}$ \\
\hline
\end{tabular}

$\mathrm{HC}$ : homemade concentrate, $\mathrm{CC}$ : commercial concentrate pellet, BGR: black gram crop residue BW: body weight, NS: non-significance, *: $\mathrm{P}<0.05$, **: $\mathrm{P}<0.01$

Table 3. Increased lengths of body parts of local male calves by two types of concentrates

\begin{tabular}{|l|l|l|l|}
\hline & HC & CC & P-value \\
\hline a. Body length & & & \\
\hline Initial length $(\mathrm{cm})$ & 91.1 & 92.4 & \\
\hline Final length $(\mathrm{cm})$ & 109 & 113 & \\
\hline Increased length $(\mathrm{cm})$ & 17.9 & 20.6 & NS \\
\hline b. Chest girth & & & \\
\hline Initial length $(\mathrm{cm})$ & 115.4 & 120.2 & \\
\hline Final length $(\mathrm{cm})$ & 129.4 & 137 & \\
\hline Increased length $(\mathrm{cm})$ & 14.0 & 16.8 & NS \\
\hline c. Wither height & & & \\
\hline Initial height $(\mathrm{cm})$ & 106.7 & 107.9 & \\
\hline Final height $(\mathrm{cm})$ & 109.9 & 112.4 & \\
\hline Increased height $(\mathrm{cm})$ & 3.2 & 4.4 & NS \\
\hline d. Rump height $(\mathrm{cm})$ & & & \\
\hline Initial height $(\mathrm{cm})$ & 109.4 & 112.9 & \\
\hline Final height $(\mathrm{cm})$ & 115.3 & 119.6 & \\
\hline Increased height $(\mathrm{cm})$ & 5.9 & 6.7 & NS \\
\hline
\end{tabular}

NS: non-significance

Table 4. Mean values of concentrate feed cost

\begin{tabular}{|l|l|l|l|l|l|l|}
\hline $\begin{array}{l}\text { Treatment } \\
\text { Group }\end{array}$ & $\begin{array}{l}\text { Ingredients of } \\
\text { concentrate }\end{array}$ & $\begin{array}{l}\text { Ingredients } \\
(\%)\end{array}$ & $\begin{array}{l}\text { Concentrate Cost } \\
(\mathrm{MMK} / \mathrm{kg})\end{array}$ & $\begin{array}{l}\text { Concentrate Given } \\
\text { (kg/calf) }\end{array}$ & $\begin{array}{l}\text { Concentrate Cost } \\
\text { (MMK/calf/day) }\end{array}$ & P-value \\
\hline HC & Cottonseed meal & 66.67 & 332 & 1.48 & 491.36 & $* * *$ \\
\cline { 2 - 6 } & Lablab bean husk & 33.33 & & 1.67 & 774.88 & \\
\hline CC & $\begin{array}{l}\text { Palmkernal meal, } \\
\text { Corn, Rice/Wheat } \\
\text { bran, Green bean } \\
\text { shell, Dried } \\
\text { Distiller Grains }\end{array}$ & ND & 464 & & & \\
\hline
\end{tabular}

MMK: Myanmar Money Kyats; ND: not determined; ***: $\mathrm{p}<0.0001$ 
calves $(55.10 \mathrm{~kg}$ and $612.70 \mathrm{~g} / \mathrm{day})$. The mean FCE of two grouped calves was 7.83 for CC and 7.80 for HC. However, there were no significant differences in those three measurements for the two grouped calves fed basal diet BGR. These occurrences mean that homemade concentrate could response the parallel efficiency of commercial concentrate fed the Pyar Sein calves; and probably would be seen associative effect of LLBH and cottonseed meal in HC supplement on rumen fermentation parameters and digesta kinetics. This assumption was supported by Ramachandra et al. (2012) who reported that pulse by-products based on complete diets can increase the rumen microbial biomass synthesis and improve in vitro DM, NDF and ADF digestibility (Konka et al. 2015). The MDG result in the current research was consistent with previous studies (Ba et al. 2008b; Dung et al., 2013). Purwin et al. (2015) suggested that the level of supplementary concentrate in steer diets influenced weight gains, feed conversion ratio and utilization efficiency of concentrate. However, different levels of condensed molasses fermentation soluble did not affect weight gain in Korea native cattle (Ha, 1993).

Mean values of initial and final body length, chest girth, wither height and rump height and increased lengths of them are displayed in Table 3. There were no differences in the growth of body parts measured of local Pyar Sein male calves between HC and CC groups within three months ( $p>0.05$ ). Thus, there were no negative growths such as body length, chest girth, wither height and rump height of local male calves fed BGR supplemented with HC. Nowadays, in modern farm system, animal growth performance is generally measured with average daily weight gain, and body size is commonly evaluated by increase of chest girth and body length (Ozkaya and Bozkurt, 2009). Besides, cattle body weight also has a positive correlation with body dimensions such as body length, hip height and chest girth (Puspitaningrum, 2009).

In the aspect of economic point which was primarily calculated on the current animal feed prices from local market (Table 4) found that the price of homemade concentrate was MMK 332/Kg and that of commercial concentrate was MMK 464/Kg, respectively. Cost of producing homemade concentrate is $28.4 \%$ (MMK132) less than that of commercial concentrate. The feeding concentrate cost $(491.36 \mathrm{MMK} / \mathrm{calf} /$ day) for HC group was significantly less than that for CC group (774.88MMK/calf/day) in the current feeding experiment. Therefore, the use of homemade concentrate made from locally available ingredients may optimize and economize the production of livestock through assessed this feeding trial in Pyar Sein calves for small-scale farmers.

\section{Conclusion}

Black gram crop residue could be applied as basal roughage source and feeding homemade concentrate did not show adverse effect on growth performance of Pyar Sein male calves in terms of DMI, MDG, FCE, body length, chest girth, wither height and rump height. These findings suggest that $20 \% \mathrm{CP}$ level in homemade concentrate and $1 \%$ of live body weight concentrate are recommendable for local cattle production during fattening process.

\section{Acknowledgement}

The authors thanked the JAPFA COMFEED MYANMAR Pte. Ltd., for Education and Research Development project for financially supporting this research.

\section{Authors' contribution}

All authors participated to the study concept and design. Material preparation, data collection and analysis were performed by KSW, ZTZK and KKL. The first draft of the manuscript was written by KSW; YA, ZTZK, KKL and HLO were revised the manuscript. All authors read and approved the final manuscript.

\section{References}

1) Arulnathan N, Murugan M, Balakrishnan V. 2013. Proximate principles, fiber fraction and mineral content of black gram husk (Vigna mungo). International Journal of Livestock Research 3: 24-30

2) AOAC. 1990. Official methods of analysis. $15^{\text {th }}$ ed. Arlington (VA): Association of Official Analytical Chemists.

3) Ba NX, Van NH, Ngoan LD, Leddin CM, Doyle PT. 2008b. Effects of amount of concentrate supplement on forage intake, diet digestibility and live weight gain in yellow cattle in Vietnam. Asian-Australasian Journal of Animal Science. 21(12): 1736-1744.

4) Dey A, De PS, Gangopadhyay PK. 2017. Black gram (Vigna Mungo L.) foliage supplementation to crossbred cows: effects on feed intake, nutrient digestibility and milk production. Asian-Australian Journal of Animal Science. 30(2):187-191.

5) Dung DV, Ba NX, Van NH, Phung LD, Ngoan LD, Cuong VC, Yao W. 2013. Practice on improving fattening local cattle production in Vietnam by increasing crude protein level in concentrate and concentrate level. Tropical Animal Health and Production 45 (7):1619-26. 
6) GNLM. 2020. Exports of cattle, animal products down by $\$ 222.5 \mathrm{mln}$ in current FY. https://www.gnlm.com.mm/exports-of-cattle-animal-products-down-by-222-5-mln-in-current-fy/

7) Grant RJ, Van Soest RE, McDowell and Perez Jr. CB. 1974. Intake, digestibility and metabolic loss of Napier grass by cattle and buffaloes when fed wilted, chopped and whole. Journal of Animal Science 39: 423-434

8) Ha JK. 1993. Effects of supplementary CMS on feed intake, weight gain and feed requirement in Hanwoo (Korean native cattle). Paper presented at the seminar on CMS and Oligo Saccharide, Miwon Co. Korea. (Unpublished mimeo).

9) Jarrige R. 1989. Ruminant Nutrition. In: “ Recommended Allowances and Feed Tables”(ed. R. Jarrige), INRAJohn Lippy Eurotext, London, Paris. 23-32.

10) Khemsawat C, Phonbumrung T. 2008. Current status of beef production and feed industry in Indochinese countries. Page 8-16 in Proc. Symp. Establishment of a Feeding Standard of Beef Cattle and a Feed Database for the Indochinese peninsula. Oshio S, Otsuka M and Sommart K, ed. Klungnanavithaya Press, Khon Kaen, Thailand.

11) Konka RK, Dhulipalla SK, Jampala VR, Arunachalam R, Pagadala EP, Elineni RR. 2015. Evaluation of crop residue based complete rations through in vitro digestibility. Journal of Advanced Veterinary and Animal Research 2 (1): 64-68

12) Leng RA. 1990. Factors affecting the utilization of forages by ruminants under tropical conditions. Nutrition Research Review 3: 277-303.

13) Luong P, Dominic S, Ohn K and Myint A. 2015. The Myanmar Beef Industry in "Regional Workshop on Beef markets and trade in Southeast Asian and China", Ben Tre, Vietnam, $30^{\text {th }}$ November $-3^{\text {rd }}$ December 2015.

14) Muinga RW, Thorpe $\mathrm{W}$ and Topps JH. 1992. Voluntary food intake, live weight change and lactation performance of crossbred dairy cows given ad libitum Pennisetum purpureum (Napier grass vs Bana) supplemented with leucaena forage in the lowland semi-humid tropics. Animal Production. East Lothian, Scotland: Durrant. 55:331-337.

15) NLBS2018. 2019. National Livestock Baseline Survey 2018 report.

16) Ozkaya S, Bozkurt Y. 2009. The accuracy of prediction of body weight from body measurements in beef cattle. Archiv fur Tierzucht 52 (4): 371-377

17) Purwin C, Wyzlic I, Nogalski Z, Sobczuk-Szul M, Pogorzelska-Przybylek P, Lipinski K, Wierzbowska J, Starczewski M, Michalski JP. 2016. The effect of grass silage quality and supplementary concentrate levels on feed intake and fattening performance of crossbred steers. Journal of Elementology 21 (4): 1103-1113

18) Puspitaningrom D. 2009. Estimation of live weight on body size dimension of Brahman crossbred cattle. Research report. Faculty of Animal Husbandry, Brawijaya University, Malang.

19) Ramachandra B, Nagabhushana V, Thirumalesh T, Suresh BN. 2012. Evaluation of pulse by-products based complete diets for rumen degradation kinetics and microbial biomass synthesis by in vitro gas production technique. Indian Journal of Animal Nutrition 29 (2): 143-147.

20) Snedecor GW, Cochran WG. 1994. Statistical methods. ${ }^{\text {th }}$ ed. Ames: Iowa State University Press p 593.

21) Sommart, K. 1998. The use of cassava in ruminant diets based on low quality roughages. Ph.D Thesis in Ruminant Nutrition. University of Newcastle Upon Tyne, Newcastle, UK.

22) Tin Maung Soe, Khin San Mu, Tin Ngwe. 2007. Effect of groundnut, black gram and green gram residues on intake, digestibility and nitrogen utilization as supplements in goat fed rice straw. The Journal of Myanmar Veterinary Association. pp:9-18.

23) Van Soest PJ, Robertson JB, Lewis BA. 1991. Methods of dietary fiber, neutral detergent fiber and non-starch polysaccharides in relation animal nutrition. Journal of Dairy Science 74: 3583-3597.

24) Venkateswarlu S, Srinivas Kumar D, Narendranath D. 2013. Nutrient utilization in buffalo bulls fed crop residues based rations. Journal of Animal and Feed Research 3 (2): 101-105

25) Win KS, Khant S, Soe TH, Myint WT, Kyaw ZT, Lay KK. 2020. Comparative feeding of two concentrate diets on voluntary feed intake and growth performance of Pyar Sein calves in Myanmar. Journal of Livestock Science 11: 122-126

26) Win KS, Ueda K, Kondo S. 2015. Effect of grass hay proportion in a corn silage based diet on rumen digesta kinetics and digestibility in dairy cows. Animal Science Journal 86: 833-841.

27) Working Committee of Thai Feeding Standard for Ruminant (WTSR). 2010. Table of Energy and Protein Requirement. In: Nutrient Requirements of Beef Cattle in Indochinese Peninsula. ${ }^{\text {st }}$ ed; pp: 85-86. 